NBER WORKING PAPER SERIES

\title{
THE MEASURE OF MAN AND OLDER AGE MORTALITY: EVIDENCE FROM THE GOULD SAMPLE
}

\author{
Dora L. Costa \\ Working Paper 8843 \\ http://www.nber.org/papers/w8843 \\ NATIONAL BUREAU OF ECONOMIC RESEARCH \\ 1050 Massachusetts Avenue \\ Cambridge, MA 02138 \\ March 2002
}

I gratefully acknowledge the support of NIH grants AG12658 and AG10120. The views expressed herein are those of the author and not necessarily those of the National Bureau of Economic Research.

(C) 2002 by Dora L. Costa. All rights reserved. Short sections of text, not to exceed two paragraphs, may be quoted without explicit permission provided that full credit, including (C) notice, is given to the source. 
The Measure of Man and Older Age Mortality:

Evidence from the Gould Sample

Dora L. Costa

NBER Working Paper No. 8843

March 2002

JEL No. J11, I12, N31

\begin{abstract}
This paper documents differences in body size between white, black, and Indian mid-nineteenth century American men and investigates the socioeconomic and demographic determinants of frame size using a unique data set of Civil War soldiers. It finds that over time men have grown taller and heavier and have relatively less abdominal fat. Abdominal fat in young adulthood was an excellent predictor of older age mortality from ischemic heart disease or stroke. Changes in frame size explain roughly three-fifths of the mortality decline among white men between 1915 and 1988 and predict even sharper declines in older age mortality between 1988 and 2022.
\end{abstract}

\author{
Dora L. Costa \\ MIT \\ Department of Economics, E52-274C \\ 50 Memorial Drive \\ Cambridge, MA 02142 \\ and NBER \\ costa@mit.edu
}




\section{Introduction}

Human physiology has changed dramatically over the last 300 years. Body size increased by over 50 percent and average longevity increased by more than 100 percent (Fogel and Costa 1997). Chronic disease rates at older ages decreased by almost 50 percent and rates of functional limitations by over 60 percent (Costa 2000; Costa 2002). These changes have been possible because humans have learned to control their environment. Rising wealth and advances in agriculture have improved nutritional status. Knowledge of the germ theory of disease spurred sanitary reforms that reduced infectious disease rates. Medical innovations now allow both for short-term symptom relief and for long-term control of chronic conditions.

This paper provides new evidence on changes in human physiology and their implications for older age mortality. Our evidence to date comes from extensive data on stature and relatively sparse data on weight. But, there is more to the human frame than height and weight. Fat patterning, lung capacity, and muscle strength are independent, and sometimes better, predictors of later work levels, disease, and death.

The paper documents the body size of mid-nineteenth century American men, white, black, and Indian, using a unique data set of Union Army Civil War soldiers, collected by the United States Sanitary Commission and first analyzed by Benjamin Gould (Gould 1866). It examines the predictors of body size and investigates the relationship between body size and mortality from heart disease at older ages. The findings have implications for understanding the causes underlying declines in mortality and morbidity, for assessing the living standards of past populations, and for predicting future mortality rates. 


\section{The Human Frame}

The environment shapes the human frame; it determines its height, weight, fat patterning, lung capacity, and muscular strength. Poor net nutritional status during the growing years (including the fetal stage) leads to a shorter population and poor current net nutritional status to a lighter population. Poor nutritional status arises not just from insufficient nutritional intake, but also from the demands of disease, work, and climate. In present day England shorter populations are found in counties that had higher infant mortality rates from respiratory diseases at the beginning of the century (Barker 1992). Low birth weight for gestational age babies not only grow up to be shorter (Paz et al. 1993; Lagerström et al. 1994), but they may also grow up to have greater abdominal fat deposits. Barker (1992) finds that adult waist-hip ratio falls with increasing birth weight and weight at one year of age, but did not control for gestational age. Loos et al. (2001) find that among twins the heavier twin at birth was not only taller and heavier as an adult, but, when adjusted for body mass, he had a lower waist-hip ratio, less subcutaneous fat, and more lean body mass compared to his lighter sibling. Birth weight and early life infections predict adult lung capacity. Barker (1992) finds that among adults forced expiratory volume in one second fell with decreasing birth weight even controlling for health in infancy and later socioeconomic factors, but that vital capacity and birth weight were not related. However, infections in early infancy were related both to forced expiratory volume and to forced vital capacity. In present day Guatemala babies weighing less than 2500 grams at birth not only grow up smaller, but also with less muscle strength (Martorell et al. 1996).

In the United States of the nineteenth century, infectious disease played a large role in determining stature. White men living in the major cities and in other high mortality areas were shorter than those from remote rural areas. Although there were differences in height by occupation, these were small compared to the several centimeter occupational differences in 
stature among Europeans and to urban-rural differentials that were up to $3 \mathrm{~cm}$ in the United States (Costa and Steckel 1997; Floud et al. 1990; Haines et al. 2000). An abundant food supply ensured that the poor in the United States were relatively well-fed, even in the womb. Their birth weights were high in Philadelphia by mid-twentieth century standards (Goldin and Margo 1989) and in Montreal by present day standards (Ward 1993). In contrast, European birth weights were much lower, averaging only slightly more than 3200 gm (Ward 1993).

The slave population of the United States experienced an unusual pattern of growth. Because pregnant women were over-worked and children were poorly fed, slave children at birth probably weighed an average of $2500 \mathrm{gm}$ and by four and half years of age were only at the 0.2 height centile, below the level of the poorest populations of developing countries. When slaves reached field hand age large quantities of meat were introduced into their diets and slaves experienced such remarkable catch-up growth that by adulthood they were only slightly shorter than northern, white men and were taller than most European populations (Steckel 1989). They were also heavier than northern whites (Fogel 1992).

Anthropological and bioarcheological evidence suggests that prior to extensive contact with whites, native Americans had a high standard of health. The Plains Indians enjoyed a rich and varied diet, equally distributed, and a low disease burden. They were the tallest recorded mid-nineteenth century population (Prince and Steckel 2001).

The implications of body size for mortality and morbidity have been studied extensively in recent populations, but relatively little in past populations. Costa (1993) finds that the functional relation between height and subsequent mortality is similiar among a sample of 322 Union Army recruits measured at ages 23-49 who lived to age 55 and are observed over a twenty year period and among modern, Norwegian males aged 40-59 observed over a seven year period. ${ }^{1}$ Both

\footnotetext{
${ }^{1}$ The Norwegian population is used for comparison because this population provides the largest available dataset.
} 
the Norwegian curve and the U.S. curve show that mortality first declines with height to reach a minimum at heights close to $185 \mathrm{~cm}$ and then starts to rise. A similar relationship is found between height and self-reported health status (Fogel 1997). The relationship between height and subsequent mortality is very sensitive to sample size and does not always hold up in all samples (e.g. Costa forthcoming). Height appears to be inversely related to heart and respiratory diseases and positively related to the hormonal cancers (Barker 1992).

The body mass index (BMI), defined as weight in kilograms divided by the square of height in meters, is an even stronger predictor of mortality and morbidity than height. The relation between weight and mortality among Union Army veterans measured at ages 50-64 and observed from age 50 until 75 resembles that seen among modern, Norwegian males (Costa 1993). Mortality risk first declines rapidly at low weights as BMI increases, stays relatively flat over BMI levels from the low to high twenties, then starts to rise again, but less steeply than at very low BMIs. Among modern, American males aged 50-64 the relationship between BMI and self-reported health status, the number of bed days, the number of doctors' visits, and the number of hospitalizations follows a similar U-shaped pattern (Costa 1996).

Studies of recent populations suggest that measures of central or abdominal body fat are better markers than BMI of risk of death, especially risk of fatal coronary heart disease (e.g. Folsom et al. 1993). Abdominal fat distribution is associated with antecedents of cardiovascular disease such as hypertension, non-insulin dependent diabetes, high plasma concentrations of atherogenic lipids, and low concentrations of high density lipoprotein cholesterol (Ohlson et al. 1985; Blair et al. 1984; Folsom et al. 1989). ${ }^{2}$ One very common measure of abdominal fat is the waist-hip ratio, but there is also evidence that the ratio of chest circumference to biacromial

\footnotetext{
${ }^{2}$ Atherogenic lipids such as chylomicrons, very low density lipoproteins, and low density lipoproteins accelerate the deposition of lipids in the intima of the arteries. This deposition of lipids is associated with atherosclerosis. High levels of high density lipoproteins may protect against risk of atherosclerosis, perhaps because these lipoproteins may be scavengers for excess cholesterol present in arterial walls.
} 
(shoulder) diameter and of chest circumference to standing height are significantly and directly associated with coronary heart disease (Yao et al. 1991). There is still little agreement on the exact relationship between measures of abdominal fat and mortality risk. Among men, a waisthip ratio above 0.95 or above 1 is generally considered high risk. However, in a young age group, particularly one in the military, it is rare to find men with waist-hip ratios above one. A 23-year follow-up study of WWII soldiers measured prior to discharge in 1946-47 shows that a standard deviation increase in waist-hip ratio above the mean increased mortality risk from ischaemic and cerebrovascular heart disease by up to 1.24 times and that this relationship was linear (Terry et al. 1992). Yao et al. (1991) find that measures of central body fat are linearly related to cardiovascular disease mortality, but, like BMI, they have a U-shaped relation with all cause mortality. However, Schreiner et al. (1996) argue that when waist circumference is used as a surrogate for intra-abdominal fat area in men, a quadratic term should be included in the analysis as a predictor variable.

In the United States today, blacks have smaller waist circumferences than whites at the same levels of BMI (Okoson et al. 2000). Among men (but not women) no racial differences in the relationship between central obesity and disease have been detected (Freedman et al. 1995).

The last two health indicators considered in this research are lifting capacity and lung capacity. In a world where many labored in manual jobs, lifting capacity determined work levels and productivity. Studies of recent populations have found that lung capacity is associated with respiratory tract illnesses and chronic respiratory symptoms (Martinez, Taussig, and Morgan 1990; Eisen et al 1987) and with mortality from respiratory diseases, lung cancer, and stroke (Strachan 1991; Loomis, Collman, and Kogan 1989).

Whether anthropometric measures have direct pathogenic effects or are simply markers of other processes remains unclear. Consider the case of a high waist-hip ratio. Sustained adrenal overactivity, initiated by early growth restraint, may increase abdominal fat depositions 
and separately lead to hypertension and impaired glucose tolerance. Alternatively, the distinctive biochemical characteristics of intra-abdominal fat may perturb lipid and carbohydrate metabolism thus leading to cardiovascular disease and diabetes (Barker 1992).

\section{Data}

In the early part of 1863 the United States Sanitary Commission began its inquiry into the physical and social condition of soldiers. By the end of the war it had collected data on 23,785 men, consisting of 16,900 white Union soldiers, 1146 white Union sailors, 68 white Union marines, 2883 black Union soldiers (recruited both in the North and in the South), 1980 Confederate prisoners of war, 517 Indians (mainly Iroquois from upstate New York), and 291 students. Trained examiners armed with andrometers, spirometers, dynamometers, facial angle instruments, platform balances, calipers, and measuring tape measured men's body dimensions, weight, lifting strength, and vital capacity, and obtained basic demographic and socio-economic information. The original forms filled in by the examiners are available in the New York Public Library. With the exception of the student records, all available records were put into machine readable form, yielding a sample of 20,213 men of which 2591 are black, 339 are Indians, 1417 are Confederate prisoners of war, and the remainder are white Union soldiers and sailors. A subsample of 521 white Union soldiers who survived to 1900 were linked to their pension records, providing mortality information.

The Sanitary Commission collected the sample (henceforth referred to as the Gould sample) by sending sixteen examiners to specific locations, including Washington, where the armies of the Potomac and the West were concentrated. Compared to the Union Army as a whole, the location of the examiners increases the proportion of recruits who were born in the Middle Atlantic (especially New York City) relative to the Union Army. Therefore, the average recruit 
was shorter and the proportion of recruits who were farmers was smaller than in the Union Army (see the Data Appendix for details). The average recruit in the Gould sample was also more likely to be native-born. Because the Union Army was representative of the northern population in terms of geographic distribution, foreign birth, and household wealth (Fogel 1993), the men in the Gould sample are therefore more urban, native-born, and shorter than the population as a whole. Work with previous samples of Union Army veterans indicates that no biases are introduced in linkage to the pension records (Fogel 1993).

The paper focuses on 7 anthropometric indicators: height (an indicator of frame size), BMI (a measure of total body fat), waist-hip ratio, the ratio of chest circumference to shoulder breadth, the ratio of chest circumference to height (all indicators of central body fat), lifting strength (an indicator of muscle strength), and vital capacity (a measure of lung capacity). The quality of these measurements is discussed in the Data Appendix, which also provides details about the other anthropometric variables available in the sample. Vital capacity is not comparable to modern measures, but can still be compared across different groups within the Gould sample. Socio-economic and demographic controls are race, birth place (classified as U.S., Ireland, Germany, Great Britain, Canada, and other foreign), a dummy indicating if the native-born were born in a city with a population of 50,000 or more in 1860 , occupation (classified as agricultural, professional or proprietor, artisan, and laborer), whether the recruits' parents were native-born, education (classified as none, limited common school, good common school, high school, collegiate, and professional), whether the recruit was a seaman, and year of enlistment.

Linkage to the pension records provides information on year and cause of death. The pension sample is further restricted to the 51 percent of men whose pension records provide information on cause of death. For the most part, these were men with a surviving spouse and men who lived longer. If the men in this sample are on whole healthier, then I am likely to underestimate the impact of anthropometric measures on older age mortality. Causes of death are 
coded as death from ischemic or cerebrovascular heart disease and death from other causes. ${ }^{3}$

Height and body fat measures in the Gould sample are compared with those of the post World War II military from two anthropometric surveys used for designing uniforms and equipment for military personnel. These are the 1950 Survey of Flying Personnel conducted by the Air Force and the 1988 Anthropometric Survey of the U.S. Army. The latter survey includes blacks. The two surveys provide data on height, BMI, waist-hip ratio, the ratio of chest circumference to shoulder breadth, and of chest circumference to height. The measurements in these surveys are comparable to those in the Gould sample (see the Data Appendix for further details).

\section{Trends}

Table 1 shows that, with the exception of height and lifting capacity, reweighting the white Gould sample so it is geographically representative of the white Union Army has very little effect on the means of anthropometric measures. The analysis will therefore focus on the unweighted sample.

Table 1 shows that there were substantial differences in anthropometric characteristics across races. Indians were the tallest, the heaviest, had the highest waist-hip and chest-shoulder ratios, and had the greatest lifting strength and vital capacity. At ages 31-35 they were two cm taller than all whites and one cm taller than native-born whites in the unweighted Gould sample. However, differences between whites and Indians in height and vital capacity in the youngest age groups were small, suggesting that by the 1840s, Indians in New York State had experienced a relative deterioration in health. Note also that vital capacity does not decline after age 25 , as would be expected, suggesting that older cohorts of Indians were in better health than younger

\footnotetext{
${ }^{3}$ Ischemic includes all mentions of atherosclerosis, arteriosclerosis, coronary occlusion, coronary thrombosis, and angina and also undefined heart disease. This heart disease category excludes valvular heart disease and myocarditis.
} 
Table 1: Anthropometric and Health Indicators of Union Soldiers in the Gould Sample by Race and Age

\begin{tabular}{|c|c|c|c|c|c|c|c|c|}
\hline & Age & $\begin{array}{l}\text { Height } \\
(\mathrm{cm})\end{array}$ & BMI & $\begin{array}{l}\text { Waist- } \\
\text { hip } \\
\text { ratio }\end{array}$ & $\begin{array}{c}\text { Chest- } \\
\text { shoulder } \\
\text { ratio }\end{array}$ & $\begin{array}{l}\text { Chest- } \\
\text { height } \\
\text { ratio }\end{array}$ & $\begin{array}{l}\text { Lifting } \\
\text { strength } \\
(\mathrm{kg})\end{array}$ & $\begin{array}{c}\text { Vital } \\
\text { capacity } \\
\text { (1) }\end{array}$ \\
\hline \multicolumn{9}{|l|}{ White } \\
\hline & $16-20$ & 168.817 & 22.048 & 0.849 & 2.506 & 0.521 & 139.696 & 3.069 \\
\hline & $21-25$ & 170.848 & 22.892 & 0.855 & 2.570 & 0.536 & 154.728 & 3.139 \\
\hline & $26-30$ & 170.845 & 23.099 & 0.863 & 2.596 & 0.542 & 156.333 & 2.984 \\
\hline & $31-35$ & 170.623 & 23.151 & 0.865 & 2.655 & 0.546 & 159.447 & 2.900 \\
\hline \multicolumn{9}{|l|}{$\begin{array}{l}\text { White, } \\
\text { Reweighted }\end{array}$} \\
\hline & $16-20$ & 169.007 & 22.070 & 0.848 & 2.466 & 0.520 & 140.249 & 3.075 \\
\hline & $21-25$ & 171.496 & 22.991 & 0.853 & 2.538 & 0.536 & 157.784 & 3.172 \\
\hline & $26-30$ & 171.749 & 23.175 & 0.859 & 2.581 & 0.544 & 160.615 & 3.036 \\
\hline & $31-34$ & 171.775 & 23.194 & 0.860 & 2.608 & 0.543 & 164.258 & 2.932 \\
\hline \multicolumn{9}{|l|}{ Black } \\
\hline & $16-20$ & 166.333 & 22.517 & 0.859 & 2.431 & 0.520 & 133.005 & 2.633 \\
\hline & $21-25$ & 168.110 & 23.827 & 0.858 & 2.375 & 0.534 & 150.954 & 2.731 \\
\hline & $26-30$ & 169.386 & 24.057 & 0.861 & 2.431 & 0.538 & 155.953 & 2.712 \\
\hline & $31-35$ & 169.821 & 23.861 & 0.865 & 2.446 & 0.537 & 162.285 & 2.734 \\
\hline \multicolumn{9}{|l|}{ Indian } \\
\hline & $16-20$ & 167.685 & 22.589 & 0.865 & 2.451 & 0.535 & 143.259 & 3.080 \\
\hline & $21-25$ & 171.011 & 23.944 & 0.872 & 2.622 & 0.543 & 163.025 & 3.100 \\
\hline & $26-30$ & 173.289 & 24.781 & 0.880 & 2.803 & 0.547 & 179.428 & 3.073 \\
\hline & $31-35$ & 172.986 & 24.875 & 0.884 & 2.772 & 0.548 & 181.198 & 3.107 \\
\hline
\end{tabular}

Note: The data include seamen and exclude men in low vigor. Vital capacity is not comparable to modern measures. Indians are largely Iroquois from upstate New York. The reweighted white sample was reweighted to have the same distribution of region of birth as the Union Army as a whole. 
Table 2: Anthropometric Measures of Military Men Circa 1950 and 1988

\begin{tabular}{|c|c|c|c|c|c|c|c|}
\hline Year & Race & Age & $\begin{array}{l}\text { Height } \\
\text { (cm) }\end{array}$ & BMI & $\begin{array}{l}\text { Waist- } \\
\text { hip } \\
\text { ratio }\end{array}$ & $\begin{array}{c}\text { Chest- } \\
\text { shoulder } \\
\text { ratio }\end{array}$ & $\begin{array}{l}\text { Chest- } \\
\text { height } \\
\text { ratio }\end{array}$ \\
\hline 1946- & White & $16-20$ & & 22.7 & 0.820 & & \\
\hline \multirow[t]{3}{*}{1947} & & $21-25$ & & 23.2 & 0.833 & & \\
\hline & & $26-30$ & & 23.8 & 0.850 & & \\
\hline & & $31-35$ & & 24.0 & 0.862 & & \\
\hline \multirow[t]{4}{*}{1950} & White & & & & & & \\
\hline & & $21-25$ & 175.797 & 23.288 & 0.825 & 2.409 & 0.547 \\
\hline & & $26-30$ & 175.682 & 24.110 & 0.848 & 2.472 & 0.563 \\
\hline & & $31-35$ & 175.290 & 24.687 & 0.861 & 2.507 & 0.571 \\
\hline \multirow[t]{5}{*}{1988} & White & & & & & & \\
\hline & & $16-20$ & 176.026 & 24.382 & 0.830 & 2.455 & 0.550 \\
\hline & & $21-25$ & 175.644 & 24.956 & 0.847 & 2.491 & 0.563 \\
\hline & & $26-30$ & 177.452 & 25.308 & 0.860 & 2.517 & 0.566 \\
\hline & & $31-35$ & 175.310 & 26.096 & 0.873 & 2.555 & 0.578 \\
\hline \multirow[t]{5}{*}{1988} & Black & & & & & & \\
\hline & & $16-20$ & 174.690 & 24.240 & 0.822 & 2.419 & 0.543 \\
\hline & & $21-25$ & 175.912 & 25.341 & 0.828 & 2.425 & 0.552 \\
\hline & & $26-30$ & 176.620 & 26.191 & 0.845 & 2.480 & 0.563 \\
\hline & & $31-35$ & 176.181 & 26.100 & 0.860 & 2.481 & 0.566 \\
\hline
\end{tabular}

The 1946-1947 data are from published tabulations in Terry et al. (1992). The 1950 data are from the 1950 Survey of Flying Personnel. No numbers are given for men age 16-20 because the sample sizes were too small. The 1988 data are from the 1988 Anthropometric Survey of the U.S. Army.

cohorts. At younger ages (when they were still growing), blacks were the shortest, but by older ages almost achieved the heights of whites. Blacks' vital capacity was lower at all ages (and does not decline with age), but their other anthropometric measures were comparable.

Over a span of one hundred years, men in the military have become taller and heavier, but their waist-hip ratios and chest-shoulder ratios have not increased (see Table 2). The heights of white Americans age 26-30 rose from 171 to $177 \mathrm{~cm}$ in 1988. The BMIs of white soldiers in the oldest age group rose from 23 to 26 . Note that the increase in BMI is more pronounced at older ages, a phenomenon previously noted in Costa and Steckel (1997) and attributable to the 
Table 3: Differences in Central Body Fat Between the Gould Sample and the Post-World War II Military by Race Controlling for Age and BMI

\begin{tabular}{lrrrrrr}
\hline \hline \multirow{2}{*}{ Year } & \multicolumn{2}{c}{ Waist-hip ratio } & \multicolumn{2}{c}{ Chest-shoulder ratio } & \multicolumn{2}{c}{ Chest-height ratio } \\
& White & Black & White & Black & White & Black \\
\hline 1950 & $-0.031^{\ddagger}$ & & $-0.174^{\ddagger}$ & & $0.011^{\ddagger}$ & \\
& $(0.001)$ & & $(0.008)$ & & $(0.001)$ & \\
1988 & $-0.027^{\ddagger}$ & $-0.034^{\ddagger}$ & $-0.123^{\ddagger}$ & -0.012 & $0.007^{\ddagger}$ & $0.005^{\ddagger}$ \\
& $(0.002)$ & $(0.003)$ & $(0.012)$ & $(0.016)$ & $(0.001)$ & $(0.001)$ \\
Adjusted $\mathrm{R}^{2}$ & 0.199 & 0.251 & 0.044 & 0.029 & 0.336 & 0.520 \\
\hline \hline
\end{tabular}

Coefficients indicate the difference relative to the Gould sample and are from a regression which included BMI and dummies for age categories. The foreign-born were excluded from the sample. Standard errors are in parentheses. The symbol $\ddagger$ indicates that the coefficient is significantly different from 0 at the 1 percent level.

accumulated effects of work intensity and of working conditions, high rates of chronic disease at older ages, and the accumulated effects of differences in nutritional intakes and physical activity. Although the BMIs of men circa 1950 were greater than those of Civil War soldiers, the waist-hip and chest-shoulder ratios of Civil War soldiers were greater. Controlling for BMI, both waist-hip and chest-shoulder ratios were significantly greater in the Gould sample than in either the 1950 or 1988 military (see Table 3). Chest-height ratio, however, was smaller in the Gould sample.

Tables 1 and 2 also show that whereas in the Gould sample blacks and whites are similar in terms of central body fat, in 1988 measures of central body fat were lower in blacks even when their BMIs were greater. Controlling for BMI and age with ordinary least squares regressions shows that all measures of central body fat are statistically significantly smaller in blacks than in whites. The difference in ratios was 0.02 for waist-hip, 0.07 for chest-shoulder, and 0.01 for chest-height. The absence of a difference between blacks and whites in measures of central body fat in the Gould sample may therefore be an indicator of the greater environmental stress faced by blacks in the mid-nineteenth century.

Anthropometric measures in the Gould sample are not highly correlated (see Table 4). 
Table 4: Correlation of Anthropometric and Health Indicators in the Gould Sample

\begin{tabular}{|c|c|c|c|c|c|c|c|}
\hline & $\begin{array}{l}\text { Height } \\
(\mathrm{cm})\end{array}$ & BMI & $\begin{array}{l}\text { Waist- } \\
\text { hip } \\
\text { ratio }\end{array}$ & $\begin{array}{l}\text { Chest- } \\
\text { shoulder } \\
\text { ratio }\end{array}$ & $\begin{array}{l}\text { Chest- } \\
\text { height } \\
\text { ratio }\end{array}$ & $\begin{array}{c}\text { Lifting } \\
\text { strength } \\
(\mathrm{kg})\end{array}$ & $\begin{array}{c}\text { Vital } \\
\text { capacity } \\
\text { (1) }\end{array}$ \\
\hline Height $(\mathrm{cm})$ & 1.000 & & & & & & \\
\hline BMI & -0.031 & 1.000 & & & & & \\
\hline Waist-hip ratio & -0.037 & 0.184 & 1.000 & & & & \\
\hline Chest-shoulder ratio & 0.121 & 0.065 & 0.007 & 1.000 & & & \\
\hline Chest-height ratio & -0.093 & 0.313 & 0.098 & 0.540 & 1.000 & & \\
\hline Lifting strength (kg) & 0.319 & 0.284 & 0.037 & 0.107 & 0.112 & 1.000 & \\
\hline Vital capacity (1) & 0.366 & 0.071 & -0.010 & 0.089 & 0.050 & 0.302 & 1.000 \\
\hline
\end{tabular}

Correlations are for men of all races age 16-35 and exclude those in low vigor.

The measure of abdominal fat that is most strongly correlated with BMI is chest-height ratio. The correlation between BMI and waist-hip ratio is low. Correlations, particularly those between BMI and abdominal fat measures, are much stronger in the modern army (see Table 5). This pattern would be expected if excessive nutritional intake determines waist-hip ratio today but if poor net nutritional intake determined waist-hip ratio in the past.

\section{Anthropometric Measures: Correlates}

Examining the correlates of anthropometric measures in the Gould sample, particularly race, foreign birth, size of city of birth, parents' foreign birth, occupation, and education provides information on how different groups fared controlling for observable demographic and socioeconomic factors and on the links between adverse conditions and outcomes.

Two different sets of ordinary least squares regressions are shown, of the form

$$
y_{i}=\beta_{0}+A_{i} \beta_{A}+R_{i}^{\prime} \beta_{R}+N_{i}^{\prime} \beta_{N}+O_{i}^{\prime} \beta_{O}+\beta_{V} V_{i}+\beta_{S} S_{i}+M_{i}^{\prime} \beta_{M}
$$


Table 5: Correlation of Anthropometric Measures in the 1988 Army

\begin{tabular}{lccccc}
\hline \hline & $\begin{array}{c}\text { Height } \\
(\mathrm{cm})\end{array}$ & BMI & $\begin{array}{c}\text { Waist- } \\
\text { ratio }\end{array}$ & $\begin{array}{c}\text { Chest- } \\
\text { shoulder } \\
\text { ratio }\end{array}$ & $\begin{array}{c}\text { Chest- } \\
\text { height } \\
\text { ratio }\end{array}$ \\
\hline Height & 1.000 & & & & \\
BMI & 0.015 & 1.000 & & & \\
Waist-hip ratio & -0.063 & 0.390 & 1.000 & & \\
Chest-shoulder ratio & -0.013 & 0.694 & 0.460 & 1.000 & \\
Chest-height ratio & -0.246 & 0.849 & 0.534 & 0.787 & 1.000 \\
\hline \hline
\end{tabular}

The correlations are across both white and black men.

and

$$
y_{i}=\beta_{0}+A_{i}^{\prime} \beta_{A}+P_{i}^{\prime} \beta_{P}+\beta_{C} C_{i}+O_{i}^{\prime} \beta_{O}+E_{i}^{\prime} \beta_{E}+\beta_{V} V_{i}+\beta_{S} S_{i}+M_{i}^{\prime} \beta_{M}
$$

where the first regression is for all races and nativities and the second regression is restricted to native-born whites. The dependent variable $y_{i}$ is either height, BMI, waist-hip ratio, chestshoulder ratio, chest-height ratio, lifting strength, or vital capacity. The independent variables include a vector of anthropometric controls $(A)$. These are BMI in the case of the abdominal fat measures, height and BMI in the case of lifting strength, and height in the case of vital capacity. Additional controls include sets of dummies for race $(R)$, nativity $(N)$, occupation $(O)$, and parents' birth place $(P)$, a dummy equal to one if the man was born in a city with a population of 50,000 in $1850(C)$, dummies for education $(E)$, a dummy variable equal to one if the man was in low vigor $(V)$, a dummy variable equal to one if the man was a seaman $(S)$, and a set of miscellaneous controls $(M)$ comprising age dummies, year of enlistment dummies, and dummies indicating missing or inapplicable information for place of birth, occupation, education, and year of enlistment. Robust standard errors, clustering on the 16 examiners, are given.

Tables 6,7 , and 8 confirm that differences in anthropometric characteristics across races 
were substantial. Indians were the tallest and had a greater BMI than whites. Blacks were the shortest and had the highest BMI. Note that because of their relatively small stature a higher BMI would lower their mortality risk and therefore may explain why the mortality rates of blacks and whites were not significantly different from each other above age 15 (Fogel 1992). ${ }^{4}$ Compared to whites, blacks had significantly lower lifting strength and vital capacity. The anthropometric characteristics of blacks who enlisted in free, northern states and those who enlisted in the south were similar. Central body fat did not differ between blacks and whites, but recall that in recent data blacks' measures of central body fat are significantly lower. Central body fat was greater among Indians than among whites, though this could reflect racial differences in body morphology.

Tables 6,7 , and 8 show that there were also substantial differences by nativity and occupation. The foreign-born (with the exception of Canadians) were shorter than the nativeborn. Only Germans made up for their short heights with a greater BMI. The waist-hip ratios of the foreign-born were greater than those of the native-born and their lifting strength was smaller. Men working in agriculture were taller, heavier, had less abdominal fat, and had more lifting strength than men in non-agricultural occupations. Seamen were shorter, heavier, had more abdominal fat, and less lifting strength. Gould (1869) argued that the short heights of seamen were not due to the navy selecting shorter men, but to the hardship of a seafaring life while still in the growing years (up to age 25 in the nineteenth century). Finally, note that war-time experience, proxied by being in low vigor, affects only BMI, lifting strength, and vital capacity.

Tables 9, 10, and 11 examine the predictors of anthropometric measures among the native-born. Restricting the sample to the native-born allows me to examine the effects of parents' nativity, size of city of birth, and education. Having a US-born father and mother significantly increases average height relative to having parents who are born abroad and there

\footnotetext{
${ }^{4}$ Among Norwegian men age 50-64, mortality risk is minimized at higher weights for the short than for the tall. For a tables of values see (Fogel 1993).
} 
Table 6: Height and BMI OLS Regressions

\begin{tabular}{lrrrr}
\hline \hline & \multicolumn{2}{c}{ Height $(\mathrm{cm})$} & \multicolumn{2}{c}{ BMI } \\
& $\begin{array}{c}\text { Coefi- } \\
\text { cient }\end{array}$ & $\begin{array}{c}\text { Std } \\
\text { Err }\end{array}$ & $\begin{array}{c}\text { Coefi- } \\
\text { cient }\end{array}$ & $\begin{array}{c}\text { Std } \\
\text { Err }\end{array}$ \\
\hline Dummy=1 if & & & & \\
$\quad$ White & $0.778^{*}$ & 0.398 & $0.556^{\ddagger}$ & 0.164 \\
Indian & $-2.459^{\ddagger}$ & 0.309 & $0.783^{\dagger}$ & 0.303 \\
Black & & & & \\
Dummy=1 if born in & & & & \\
U.S. & $-1.312^{\ddagger}$ & 0.342 & 0.023 & 0.142 \\
Ireland & $-2.555^{\ddagger}$ & 0.734 & $0.898^{\ddagger}$ & 0.310 \\
Germany & -0.237 & 0.425 & 0.141 & 0.139 \\
Canada & $-3.196^{\ddagger}$ & 0.192 & -0.058 & 0.132 \\
Great Britain & $-2.013^{\ddagger}$ & 0.576 & 0.232 & 0.173 \\
Other foreign country & & & & \\
Dummy=1 if occupation & & & & \\
Agricultural & & & \\
Professional or proprietor & $-1.222^{\ddagger}$ & 0.285 & $-0.543^{\ddagger}$ & 0.118 \\
Artisan & $-0.962^{\ddagger}$ & 0.101 & $-0.256^{\dagger}$ & 0.094 \\
$\quad$ Laborer & $-1.016^{\ddagger}$ & 0.141 & -0.055 & 0.084 \\
Dummy=1 if in low vigor & -0.098 & 0.130 & $-0.708^{\ddagger}$ & 0.056 \\
Dummy=1 if seaman & $-1.755^{\ddagger}$ & 0.566 & $0.202^{\dagger}$ & 0.085 \\
$\mathrm{R}^{2}$ & 0.0787 & & 0.098 & \\
Observations & 16,438 & & 16,273 & \\
\hline \hline
\end{tabular}

Covariates include age dummies, year of enlistment dummmies, and dummies indicating missing or unapplicable information for place of birth, occupation, and year of enlistment. The constant term is not shown. Robust standard errors (clustering on the examiner) are given. The symbols $*, \dagger$, and $\ddagger$ indicate that the coefficient is significantly different from 0 at the 10,5 , and 1 percent level, respectively. 
Table 7: Waist-hip, Chest-Shoulder, and Chest-Height Ratios OLS Regressions

\begin{tabular}{|c|c|c|c|c|c|c|}
\hline & \multicolumn{2}{|c|}{$\begin{array}{l}\text { Waist-hip } \\
\text { Ratio }\end{array}$} & \multicolumn{2}{|c|}{$\begin{array}{l}\text { Chest-Shoulder } \\
\text { Ratio }\end{array}$} & \multicolumn{2}{|c|}{$\begin{array}{l}\text { Chest-Height } \\
\text { Ratio }\end{array}$} \\
\hline & $\begin{array}{l}\text { Coefi- } \\
\text { cient }\end{array}$ & $\begin{array}{l}\text { Std } \\
\text { Err }\end{array}$ & $\begin{array}{l}\text { Coefi- } \\
\text { cient }\end{array}$ & $\begin{array}{l}\text { Std } \\
\text { Err }\end{array}$ & $\begin{array}{c}\text { Coefi- } \\
\text { cient }\end{array}$ & $\begin{array}{l}\text { Std } \\
\text { Err }\end{array}$ \\
\hline BMI & $0.004^{\ddagger}$ & 0.001 & -0.007 & 0.010 & $0.008^{\ddagger}$ & 0.001 \\
\hline $\begin{array}{l}\text { Dummy }=1 \text { if } \\
\text { White }\end{array}$ & & & & & & \\
\hline Indian & $0.008^{\dagger}$ & 0.004 & 0.067 & 0.133 & $0.005^{\ddagger}$ & 0.001 \\
\hline Black & 0.002 & 0.006 & -0.146 & 0.147 & -0.006 & 0.005 \\
\hline $\begin{array}{l}\text { Dummy }=1 \text { if born in } \\
\text { U.S. }\end{array}$ & & & & & & \\
\hline Ireland & $0.011^{\ddagger}$ & 0.003 & $-0.177^{\ddagger}$ & 0.042 & 0.003 & 0.003 \\
\hline Germany & 0.012 & 0.008 & 0.029 & 0.074 & 0.001 & 0.003 \\
\hline Canada & 0.002 & 0.003 & $-0.138^{\ddagger}$ & 0.039 & 0.000 & 0.001 \\
\hline Great Britain & $0.015^{\ddagger}$ & 0.005 & -0.057 & 0.082 & 0.016 & 0.010 \\
\hline Other foreign country & $0.007^{*}$ & 0.004 & -0.070 & 0.060 & -0.001 & 0.004 \\
\hline $\begin{array}{l}\text { Dummy }=1 \text { if occupation } \\
\text { Agricultural }\end{array}$ & & & & & & \\
\hline Professional or proprietor & $-0.009^{\ddagger}$ & 0.002 & $-0.152^{\ddagger}$ & 0.033 & $-0.005^{\ddagger}$ & 0.001 \\
\hline Artisan & -0.002 & 0.002 & $-0.091^{\ddagger}$ & 0.025 & $-0.002^{\ddagger}$ & 0.001 \\
\hline Laborer & -0.003 & 0.002 & $-0.111^{\ddagger}$ & 0.034 & $-0.002^{\ddagger}$ & 0.001 \\
\hline Dummy $=1$ if in low vigor & -0.004 & 0.003 & -0.056 & 0.039 & 0.000 & 0.001 \\
\hline Dummy $=1$ if seaman & $0.016^{*}$ & 0.009 & -0.154 & 0.158 & $0.006^{\ddagger}$ & 0.002 \\
\hline Adjusted $\mathrm{R}^{2}$ & 0.046 & & 0.083 & & 0.162 & \\
\hline Observations & 11,517 & & 14,133 & & 14,152 & \\
\hline
\end{tabular}

Covariates include age dummies, year of enlistment dummmies, and dummies indicating missing or unapplicable information for place of birth, occupation, and year of enlistment. The constant term is not shown. Robust standard errors (clustering on the examiner) are given. 
Table 8: Lifting Strength and Vital Capacity OLS Regressions

\begin{tabular}{lcccc}
\hline \hline & \multicolumn{2}{c}{ Lifting Strength (kg) } & \multicolumn{2}{c}{ Vital Capacity (1) } \\
& Coefi- & Std & Coefi- & Std \\
& cient & Err & cient & Err \\
\hline Height (cm) & $1.598^{\ddagger}$ & 0.053 & $0.040^{\ddagger}$ & 0.003 \\
BMI & $5.048^{\ddagger}$ & 0.214 & $0.044^{\ddagger}$ & \\
Dummy=1 if & & & & \\
White & & & & \\
Indian & 3.055 & 3.658 & 0.011 & $0 .-92$ \\
Black & $-7.398^{*}$ & 3.933 & $-0.323^{\ddagger}$ & 0.101 \\
Dummy=1 if born in & & & & \\
U.S. & & & & \\
Ireland & $-6.562^{\dagger}$ & 2.406 & -0.031 & 0.058 \\
Germany & $-7.557^{\dagger}$ & 3.430 & $-0.116^{*}$ & 0.059 \\
Canada & $3.911^{\dagger}$ & 1.420 & 0.024 & 0.025 \\
Great Britain & -3.341 & 3.264 & -0.003 & 0.047 \\
Other foreign country & -5.705 & 3.869 & $0.141^{*}$ & 0.068 \\
Dummy=1 if occupation & & & & \\
Agricultural & & & & \\
Professional or proprietor & $-2.617^{\dagger}$ & 1.006 & -0.008 & 0.034 \\
Artisan & -0.310 & 1.063 & 0.008 & 0.021 \\
Laborer & $-2.650^{\dagger}$ & 1.236 & -0.012 & 0.011 \\
Dummy=1 if in low vigor & $-20.181^{\ddagger}$ & 1.803 & $-0.251^{\ddagger}$ & 0.028 \\
Dummy=1 if seaman & $-12.959^{\ddagger}$ & 4.320 & 0.014 & 0.028 \\
Adjusted R & & & & \\
Observations & 0.243 & & & \\
\hline \hline
\end{tabular}

Covariates include age dummies, year of enlistment dummmies, and dummies indicating missing or unapplicable information for place of birth, occupation, and year of enlistment. The constant term is not shown. Robust standard errors (clustering on the examiner) are given. 
Table 9: Height and BMI OLS Regressions for Native-born Whites

\begin{tabular}{|c|c|c|c|c|}
\hline & \multicolumn{2}{|c|}{ Height $(\mathrm{cm})$} & \multicolumn{2}{|c|}{ 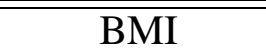 } \\
\hline & $\begin{array}{l}\text { Coefi- } \\
\text { cient }\end{array}$ & $\begin{array}{l}\text { Std } \\
\text { Err }\end{array}$ & $\begin{array}{c}\text { Coefi- } \\
\text { cient }\end{array}$ & $\begin{array}{l}\text { Std } \\
\text { Err }\end{array}$ \\
\hline \multicolumn{5}{|l|}{ Dummy $=1$ if } \\
\hline \multicolumn{5}{|l|}{ Parents born abroad } \\
\hline US-born father and mother & $1.286^{\ddagger}$ & 0.379 & $-0.143^{\ddagger}$ & 0.045 \\
\hline US-born father only & 0.944 & 0.687 & -0.255 & 0.152 \\
\hline US-born mother only & $0.389^{*}$ & 0.216 & -0.119 & 0.077 \\
\hline \multicolumn{5}{|l|}{ Dummy $=1$ if born in city with } \\
\hline population of 50,000 in 1850 & $-1.058^{\ddagger}$ & 0.234 & $-0.255^{*}$ & 0.145 \\
\hline \multicolumn{5}{|c|}{ Dummy $=1$ if occupation } \\
\hline \multicolumn{5}{|l|}{ Agricultural } \\
\hline Professional or proprietor & $-1.382^{\ddagger}$ & 0.367 & $-0.579^{\ddagger}$ & 0.102 \\
\hline Artisan & $-0.817^{\ddagger}$ & 0.177 & $-0.217^{\dagger}$ & 0.084 \\
\hline Laborer & $-0.861^{\ddagger}$ & 0.132 & $-0.094^{*}$ & 0.050 \\
\hline \multicolumn{5}{|l|}{ Dummy $=1$ if education } \\
\hline \multicolumn{5}{|l|}{ None } \\
\hline Limited common school & 0.183 & 0.178 & -0.242 & 0.164 \\
\hline Good common school & 0.221 & 0.262 & -0.251 & 0.150 \\
\hline Collegiate & -0.283 & 0.877 & $-0.766^{*}$ & 0.368 \\
\hline Professional & 1.878 & 2.322 & 0.005 & 0.292 \\
\hline Dummy $=1$ if in low vigor & -0.134 & 0.190 & -0.870 & 0.053 \\
\hline Dummy $=1$ if seaman & -0.467 & 0.311 & -0.391 & 0.286 \\
\hline Adjusted $\mathrm{R}^{2}$ & 0.060 & & 0.100 & \\
\hline Observations & 9,547 & & 9,447 & \\
\hline
\end{tabular}

Covariates include age dummies, year of enlistment dummmies, and dummies indicating missing or unapplicable information for place of birth, occupation, education, and year of enlistment. The constant term is not shown. Robust standard errors (clustering on the examiner) are given. 
Table 10: Waist-hip, Chest-Shoulder, and Chest-Height Ratios OLS Regressions for Native-born Whites

\begin{tabular}{|c|c|c|c|c|c|c|}
\hline & \multicolumn{2}{|c|}{$\begin{array}{l}\text { Waist-hip } \\
\text { Ratio }\end{array}$} & \multicolumn{2}{|c|}{$\begin{array}{c}\text { Chest-Shoulder } \\
\text { Ratio }\end{array}$} & \multicolumn{2}{|c|}{$\begin{array}{l}\text { Chest-Height } \\
\text { Ratio }\end{array}$} \\
\hline & $\begin{array}{l}\text { Coefi- } \\
\text { cient }\end{array}$ & $\begin{array}{l}\text { Std } \\
\text { Err }\end{array}$ & $\begin{array}{l}\text { Coefi- } \\
\text { cient }\end{array}$ & $\begin{array}{l}\text { Std } \\
\text { Err }\end{array}$ & $\begin{array}{l}\text { Coefi- } \\
\text { cient }\end{array}$ & $\begin{array}{l}\text { Std } \\
\text { Err }\end{array}$ \\
\hline $\mathrm{BMI}$ & $0.004^{\ddagger}$ & 0.001 & 0.007 & 0.007 & $0.008^{\ddagger}$ & 0.001 \\
\hline $\begin{array}{l}\text { Dummy }=1 \text { if } \\
\text { Parents born abroad }\end{array}$ & & & & & & \\
\hline US-born father and mother & -0.001 & 0.001 & 0.011 & 0.017 & -0.007 & 0.005 \\
\hline US-born father only & 0.001 & 0.004 & 0.017 & 0.012 & -0.003 & 0.004 \\
\hline US-=born mother only & 0.003 & 0.002 & -0.020 & 0.015 & -0.004 & 0.004 \\
\hline $\begin{array}{l}\text { Dummy }=1 \text { if born in city with } \\
\text { population of } 50,000 \text { in } 1850\end{array}$ & $-0.009^{\dagger}$ & 0.004 & -0.013 & 0.049 & $-0.004^{*}$ & 0.002 \\
\hline $\begin{array}{l}\text { Dummy }=1 \text { if occupation } \\
\text { Agricultural }\end{array}$ & & & & & & \\
\hline Professional or proprietor & $-0.010^{\ddagger}$ & 0.002 & $-0.086^{\ddagger}$ & 0.038 & $-0.004^{\ddagger}$ & 0.001 \\
\hline Artisan & -0.002 & 0.002 & -0.021 & 0.025 & -0.002 & 0.001 \\
\hline Laborer & $-0.004^{*}$ & 0.002 & -0.034 & 0.036 & -0.002 & 0.002 \\
\hline $\begin{array}{l}\text { Dummy }=1 \text { if education } \\
\text { None }\end{array}$ & & & & & & \\
\hline Limited common school & 0.003 & 0.005 & 0.087 & 0.061 & $0.004^{\ddagger}$ & 0.001 \\
\hline Limited good common school & 0.002 & 0.004 & -0.008 & 0.032 & $0.003^{\dagger}$ & 0.001 \\
\hline Collegiate & 0.001 & 0.008 & $-0.101^{\dagger}$ & 0.038 & $0.002^{*}$ & 0.001 \\
\hline Professional & $0.020^{*}$ & 0.008 & $0.227^{\ddagger}$ & 0.058 & -0.003 & 0.003 \\
\hline Dummy $=1$ if in low vigor & -0.004 & 0.004 & 0.010 & 0.030 & -0.001 & 0.001 \\
\hline Dummy $=1$ if seaman & 0.019 & 0.011 & -0.300 & 0.218 & -0.004 & 0.005 \\
\hline Adjusted $\mathrm{R}^{2}$ & 0.039 & & 0.306 & & 0.170 & \\
\hline Oservations & 5,834 & & 7,797 & & 7,808 & \\
\hline
\end{tabular}

Covariates include age dummies, year of enlistment dummmies, and dummies indicating missing or unapplicable information for place of birth, occupation, education, and year of enlistment. The constant term is not shown. Robust standard errors (clustering on the examiner) are given. 
Table 11: Lifting Strength and Vital Capacity OLS Regressions

\begin{tabular}{|c|c|c|c|c|}
\hline & \multicolumn{2}{|c|}{ "Lifting Strength (kg) } & \multicolumn{2}{|c|}{ Vital Capacity (1) } \\
\hline & $\begin{array}{l}\text { Coefi- } \\
\text { cient }\end{array}$ & $\begin{array}{l}\text { Std } \\
\text { Err }\end{array}$ & $\begin{array}{l}\text { Coefi- } \\
\text { cient }\end{array}$ & $\begin{array}{l}\text { Std } \\
\text { Err }\end{array}$ \\
\hline Height $(\mathrm{cm})$ & $1.605^{\ddagger}$ & 0.079 & $0.042^{\ddagger}$ & 0.002 \\
\hline BMI & $5.919^{\ddagger}$ & 0.238 & $0.049^{\ddagger}$ & 0.006 \\
\hline $\begin{array}{l}\text { Dummy }=1 \text { if } \\
\text { Parents born abroad }\end{array}$ & & & & \\
\hline US-born father and mother & 2.339 & 1.382 & 0.009 & 0.028 \\
\hline US-born father only & 3.871 & 3.091 & -0.029 & 0.025 \\
\hline US-born mother only & 0.421 & 1.669 & -0.024 & 0.036 \\
\hline $\begin{array}{l}\text { Dummy }=1 \text { if born in city with } \\
\text { population of } 50,000 \text { in } 1850\end{array}$ & $-3.683^{*}$ & 1.918 & -0.051 & 0.031 \\
\hline $\begin{array}{l}\text { Dummy }=1 \text { if occupation } \\
\text { Agricultural }\end{array}$ & & & & \\
\hline Professional or proprietor & 1.150 & 1.186 & 0.036 & 0.025 \\
\hline Artisan & $2.821^{\ddagger}$ & 0.781 & 0.028 & 0.027 \\
\hline Laborer & 1.660 & 1.719 & 0.026 & 0.018 \\
\hline $\begin{array}{l}\text { Dummy }=1 \text { if education } \\
\text { None }\end{array}$ & & & & \\
\hline Limited common school & 0.917 & 2.063 & $-0.094^{*}$ & 0.051 \\
\hline Good common school & 3.580 & 2.898 & 0.027 & 0.027 \\
\hline Collegiate & 1.224 & 8.766 & $0.178^{*}$ & 0.096 \\
\hline Professional & 22.952 & 21.575 & $-0.262^{*}$ & 0.142 \\
\hline Dummy $=1$ if in low vigor & -18.765 & 1.282 & -0.214 & 0.023 \\
\hline Dummy $=1$ if seaman & -17.684 & 5.012 & -0.092 & 0.106 \\
\hline Adjusted $\mathrm{R}^{2}$ & 0.243 & & 0.195 & \\
\hline Observations & 7,608 & & 9,104 & \\
\hline
\end{tabular}

Covariates include age dummies, year of enlistment dummmies, and dummies indicating missing or unapplicable information for place of birth, occupation, education, and year of enlistment. The constant term is not shown. Robust standard errors (clustering on the examiner) are given. 
is weak evidence that having just one US-born parent increases height as well, though not by as much. Men with both parents born in the US were lighter than men with parents born abroad, even controlling for height (not shown). Those born in large cities were shorter, lighter, and had less lifting strength, but they also had less abdominal fat. Recall that babies born in the Philadelphia alsmhouse had birth weights that compared favorably to those of mid-twentieth century babies (Goldin and Margo 1989), suggesting that life in a large city was best experienced in the protected environment of the womb. Finally, note that education has no predictive power, perhaps both because the labor market returns to formal education were low and because knowledge of midnineteenth medicine may only have harmed health. ${ }^{5}$

\section{Anthropometric Measures: Older Age Mortality}

Were anthropometric measures good predictors of subsequent mortality among Union Army veterans? To test this, I examined whether height, BMI, abdominal fat, muscle strength, and vital capacity predicted mortality from ischemic heart disease and stroke conditional on survival to 1900 . The discussion in this section is restricted to height, BMI, and abdominal fat because muscle strength and vital capacity were not good predictors and sample size was too small to examine deaths from respiratory disease.

I model Union Army veterans' waiting time until death from ischemic or cerebrovascular heart disease by means of a Cox proportional hazard model. The hazard, $\lambda(t)$, or the rate at which spells are completed after duration $t$ given that they last until at least $t$, is

$$
\lambda(t)=\exp \left(x^{\prime} \beta\right) \lambda_{0}(t)
$$

\footnotetext{
${ }^{5}$ Among civilians age 26 to 35 in the Third National Health and Examination Survey the better educated are taller and have a smaller waist-hip ratio (author's calculation). (Waist-hip ratio in these data is not comparable to that in the Gould sample.)
} 
where $\lambda_{0}$ is the baseline hazard and $\exp \left(x^{\prime} \beta\right)$ is the relative hazard. The covariates of primary interest are health measures and these consist of BMI and BMI squared, a dummy equal to one if the veterans' height was one standard deviation above the mean and dummies equal to one if the veterans' abdominal fat measures were one standard deviation above the mean and one standard deviation below the mean. Additional controls include age in 1900, occupation from the Gould sample (agricultural, professional or proprietor, artisan, or laborer), and a dummy equal to one if the recruit was in low vigor when measured. ${ }^{6}$ I use a competing risk framework, treating individuals who die from a cause of death other than ischemic or cerebrovascular disease as censored.

Table 12 shows that BMI and waist-hip ratios are the best predictors of subsequent mortality. Both high and low waist-hip ratios predict ischemic and stroke mortality. A waist-hip ratio that was more than one standard deviation above the mean increases mortality risk by 2.7 times relative to the mean controlling for BMI. Note that optimal BMI is 24.5 when no other anthropometric controls are included in the regression and 23.5 controlling for height and waisthip ratio, somewhat on the high end but within the generally accepted range. Dummy variables indicating high and low BMI levels were insignificant. Being tall is marginally significant only when controlling for BMI and abdominal fat. High and low chest-shoulder ratios are insignificant, but do elevate mortality risk. High and low chest-height ratios are insignificant and lower mortality risk. None of the anthropometric measures were statistically significant predictors of all-cause mortality.

How would Union Army veterans have fared if in their youth they had the characteristics of men in the 1950 military? Their 15 year all-cause mortality rate would have been lower by up to 6 percent, implying that changes in frame size explain up to three-fifths of the total decline

\footnotetext{
${ }^{6}$ Education had no predictive power.
} 
Table 12: Hazard Ratios for Death from Heart Disease Competing Risk Hazard Model

\begin{tabular}{|c|c|c|c|c|c|c|c|}
\hline & $\overline{1}$ & 2 & 3 & $\overline{4}$ & 5 & $\overline{6} 6$ & 7 \\
\hline Dummy $=1$ if tall & $\begin{array}{r}0.772 \\
(0.254)\end{array}$ & & & & & $\begin{array}{r}0.416^{*} \\
(0.221)\end{array}$ & $\begin{array}{r}0.459^{*} \\
(0.203)\end{array}$ \\
\hline BMI & & $\begin{array}{l}2.953^{*} \\
(1697)\end{array}$ & & & & $\begin{array}{r}2.811 \\
(1919)\end{array}$ & $\begin{array}{l}2.760 \\
1728\end{array}$ \\
\hline BMI squared & & $\begin{array}{r}0.978^{*} \\
(0.012)\end{array}$ & & & & $\begin{array}{r}0.978 \\
(0.014)\end{array}$ & $\begin{array}{r}0.979 \\
(0.013)\end{array}$ \\
\hline Dummy $=1$ if & & & & & & & \\
\hline $\begin{array}{l}\text { High waist- } \\
\text { hip ratio }\end{array}$ & & & $\begin{array}{r}2.344^{\dagger} \\
(0.979)\end{array}$ & & & $\begin{array}{r}2.710^{\dagger} \\
(1.153)\end{array}$ & \\
\hline $\begin{array}{l}\text { Low waist- } \\
\text { hip ratio }\end{array}$ & & & $\begin{array}{r}2.958^{\ddagger} \\
(1.165)\end{array}$ & & & $\begin{array}{c}2.973^{\ddagger} \\
(1.168)\end{array}$ & \\
\hline $\begin{array}{l}\text { High chest- } \\
\text { shoulder ratio }\end{array}$ & & & & $\begin{array}{r}1.551 \\
(0.533)\end{array}$ & & & $\begin{array}{r}1.553 \\
(0.535)\end{array}$ \\
\hline $\begin{array}{l}\text { Low chest- } \\
\text { shoulder ratio }\end{array}$ & & & & $\begin{array}{r}2.051 \\
(0.941)\end{array}$ & & & $\begin{array}{r}1.849 \\
(0.859)\end{array}$ \\
\hline $\begin{array}{l}\text { High chest- } \\
\text { height ratio }\end{array}$ & & & & & $\begin{array}{r}0.265 \\
(0.271)\end{array}$ & & \\
\hline $\begin{array}{l}\text { Low chest- } \\
\text { height ratio }\end{array}$ & & & & & $\begin{array}{r}0.570 \\
(0.184)\end{array}$ & & \\
\hline Log likelihood & -365.334 & -362.442 & -192.201 & -215.031 & -214.146 & -187.408 & -210.707 \\
\hline Observations & 235 & 234 & 138 & 153 & 153 & 137 & 152 \\
\hline
\end{tabular}

Years until death are measured from 1900. The dummy variables are equal to one if the individual is one standard deviation above (for tall or high) or below (for low) the sample mean. The symbols $*, \uparrow$, and $\ddagger$ indicate that the coefficient is significantly different from 1 at the 10,5, and 1 percent level, respectively. Standard errors in parentheses. Covariates include age in 1900, occupation from the Gould sample, and whether the recruit was in low vigor during the war. The $\log$ likelihood is for the test that all coefficients are significantly different from 1. 
in all cause mortality at older ages from 1915 to 1988. Using regression 6 in Table 12 and anthropometric means for white men from the Gould sample yields a predicted mortality rate from ischemic heart disease or stroke of 22.1 percent by 1915 . Substituting the anthropometric means for whites in the 1950 military into the regression equation decreased the heart disease mortality rate to 18.6 percent. Thus, rather having 18 percent of the sample dying from ischemic heart disease or stroke, only 15 percent would have died. ${ }^{7}$

Changes in body size predict that older age mortality rates will have declined at a much more rapid rate by 2022. Substituting in the anthropometric means for whites in the 1988 military into the regression equation decreased the heart mortality to 16.3 percent and implies a reduction in the all-cause 191515 year mortality rate of 9 percent. $^{8}$ On an annual basis the percentage point decline in mortality rates due to changes in body shape between 1915 and 1988 was 0.08 . Between 1988 and 2022 changes in body size imply an annual percentage point decline in mortality rates of 0.12 .

Black men in the mid-nineteenth century had predicted older age mortality rates that compared favorably with those of whites. Their predicted 15 year mortality rate from ischemic heart disease and stroke was 22.2 percent (using regression 6 and the sample means of black men

\footnotetext{
${ }^{7}$ The means for whites for high waist-hip ratio (above 0.91), low waist hip ratio (less than or equal to 0.81 ), tall (above $176.8 \mathrm{~cm}$ ), and BMI were $0.110,0.144,0.135$, and 22.7 in the Gould sample. The same means for whites in the 1950 military were $0.076,0.217,0.419$, and 24.0. Among men in the Gould sample linked to the pension records, 54 percent of the sample had died by 1915 and 34 percent of all deaths were from ischemic heart disease or stroke. Eighteen percent of the sample was therefore dead from ischemic heart or stroke by 1915. The regression results suggest that mortality from stroke or ischemic heart disease would have fallen by 16 percent if men had had a modern frame size. Therefore only 15 percent of the sample would have died from ischemic heart or stroke and only 51 percent of the sample would have died. (Note that this is an upper bound because men who died of heart disease may have died of other causes.) Using the epidemiological follow-up of the 1971-1974 National Health and Nutrition Examination Survey shows that, adjusting for the age-distribution, the 15 year mortality rate was 49 percent.

${ }^{8}$ The sample means for high waist-hip ratio, low waist-hip ratio, tall, and BMI in the 1988 data were $0.071,0.149$, 0.430 , and 25.1, respectively. The regression results imply that mortality from ischemic heart disease or stroke would have fallen by 26 percent or that only 13 percent of the sample would have died from ischemic heart disease or stroke. Only 49 percent of the sample would then have died from all causes.
} 
in the Gould sample and assuming that the relationship between anthropometric measures and older age mortality is the same for white and black men), the same as the predicted rate for whites. Although blacks were shorter than whites, their waist-hip ratios were the same and their greater BMIs more than made up for their shorter heights. However, today blacks' greater BMI puts them at higher risk. Using the sample means for black men in the 1988 army lowers the predicted 15 year ischemic heart disease and stroke mortality rate to only 20.9 percent. ${ }^{9}$ Note, however, that because optimal BMI is sensitive to the specification and, in large samples, lies in a broad range, the mortality declines attributable to changes in frame size may well be underestimated. ${ }^{10}$

\section{Conclusion}

This paper has shown that there have been substantial changes in the human frame over the last hundred years. Not only have men become taller and heavier, but they now have relatively less abdominal fat as well. Abdominal fat was a better predictor of mortality from ischemic heart disease or stroke than height or BMI. Changes in frame size have lowered risk of death from ischemic heart disease or stroke and explain roughly three-fifths of the mortality decline among white men between 1915 and 1988. Low birth weights and exposure to infectious disease, poor nutritional intake, and the demands of work both during the growing years and in adulthood have been pointed to as factors that contribute to a high risk frame. In the mid-nineteenth century populations that faced a higher risk of death because of their frame size included the foreign-born and large city dwellers, but not blacks. Although black slaves experienced severe nutritional

\footnotetext{
${ }^{9}$ The means for blacks for in the Gould sample were $0.103,0.106,0.087$, and 23.5 and in the 1988 army 0.018 , $0.199,0.457$, and 25.5 .

${ }^{10}$ This may explain why, assuming that the same anthropometric standards applied to whites can be applied to Indians, Indians' predicted mortality rate from ischemic heart disease and stroke was 24.6 percent, higher than that of whites or blacks.
} 
deprivation in their childhood, their heavier weights as adults provided enough protection so that their predicted older age mortality was similar to that of whites. This paper also documented frame size among Indians, providing some suggestive evidence that the Indians of upper New York state experienced a deterioration in health status.

Changes in frame size are still on-going. Men in the 1988 military were heavier and taller than men in the military of the 1950s but had the same abdominal fat patterning controlling for BMI. When these men reach late middle age in 2022, their mortality rates will be even lower than those faced by men in the late 1980s. Changes in frame size imply that, cetribus paribus, mortality rates will decline at a much more rapid rate than they have in the past. Because not all improvements in early life conditions are manifested as changes in frame size and because medical interventions at older ages are likely to continue to lower mortality rates, future declines in mortality rates may be sizable.

\section{Data Appendix}

The Gould sample was collected from the Statistical Bureau Archives of the United States Sanitary Commission in the New York Public Library. A randomly chosen sub-sample was then linked to the pension records in the National Archives. The data are available for download from the National Bureau of Economic Research, http://www.nber.org. The 1950 Survey of Flying Personnel and the 1988 Anthropometric Survey U.S. Army were obtained from the Human Systems Information Analysis Center (HSIAC) of the United States Military.

\subsection{The Gould Sample}

Every effort was made by the United States Sanitary Commission to ensure accuracy in measure-

ment. Examiners were trained, furnished with printed instructions, and provided with measuring 
instruments. Reports from Examiners were sent in weekly and returns were tabulated as soon as possible to check for errors. When a discrepancy did arise, the examiner was consulted for further information (Gould 1869: 225-228). Although later measurements were thought to be more reliable (Gould 1869: 256) there is little difference in the means. Some erroneous measurements did result from examiners' misunderstanding of the instructions, but mismeasurement was a problem only for variables that are of minor interest, such as head circumferences and facial angles (Gould 1869: 239).

Two different basic forms were used by the examiners. Form E was the first schedule used, for close to 8000 men, until it was replaced by Form EE. (See Tables 13 and 14 for the variables.) In addition, a schedule of social questions accompanied Form E. The machinereadable data set contains 6,512 Form E schedules (including 2,216 abridged versions of Form E) and 13,701 Form EE schedules. Only 252 social question schedules were found (and input) but these could not be linked to their accompanying Form E schedules.

As previously noted, relative to the Union Army the Gould sample over-represents recruits born in the Middle Atlantic, yielding a shorter sample and one with fewer farmers (see Table 15).

\subsection{Anthropometric Variables Used in the Analysis}

All variables in the Gould sample were originally measured in inches and pounds and were converted to metric units. In general men removed their shoes, coats, and waistcoats for the examination but retained their trousers and under-clothing. However, examiners were specifically instructed to measure chest circumference under the shirt. Gould (1869) describes examination procedures. Hertzberg et al. (1954) and Clauser et al. (1988) describe examination procedures for the 1950 and 1988 surveys. 


\section{Table 13: Form E Questions}

1. Number of soldier in order of examination?

2. Name of soldier? rank?

3. Regiment?

4. Entire height (in stockings - inches and tenths)?

5. Height from gound to lower part of neck (7th cervical vertebra)?

6. Height to pernaeum?

7. Breadth of neck?

8. Breadth of shoulders?

9. Breadth of pelvis?

10. Circumference of chest over the nipple (under the coat and vest - inches and tenths)?

11. Circumference of waist?

12. Length of arm - from arm pit to tip of middle finger?

13. Capacity of chest (cubic inches)? 14. Weight (lbs. and half lbs) without coat, hat, arms, or accoutrements?

15. Dynamometer?

18. Where born - country or state? county? parish or town?

19. If foreign-born, year of arrival in this country? supposed about?

20. Country of birth - of father? of mother? of grandparents?

16. In the opinion of Inspector, from appearance and statements of subject, is he of American stock of three or more generations? (In cases where this question cannot be answered with confidence, affirmatively or negatively, it will be best not pursue this examination.)

17. If so, period of immigration of ancestry? (Detail of both sides desirable.)

21. Enlisted - when? where? for what period?

22. Conjugal relation (as single, married, or widower)?

23. Age (last birthday)? 24. Former occupation?

25. Hair - color? bald? bald slightly? If so, at what age did baldness become distinct?

26. Eyes - color? distance between pupils? prominent?

27. Complexion?

28. Pulse (regular) beats per minute?

29. Respiration (number of inspirations per minute)?

30. Muscular development?

31. State if in usual vigor? if reduced by disease? wounds? recent exertion? hardship? poor fare?

32. Is he, when ordinarly well, a tougher and more vigorous man than before he entered the army? less so?

33. Condition of teeth? number lost? number decayed? number filled?

34. Head - circumference about frontal eminence and greater projection of occiput? distance between the condyloid processes of lower jaw over os frontis - longest measurement distance between condyloid processes over parietal bones?

distance from frontal eminence to protuberance of occiput?

35. facial angle?

Signature of Examiner

Place and Date of examination 
1. Number of soldier in order of examination?

2. Name of soldier? rank?

3. Regiment?

4. Entire height (in stockings - inches and tenths)?

$4 \frac{1}{2}$. Distance from tip of middle finger to level of upper margin of patella (in "attitude of the soldier")?

5. Height to lower part of neck (spine of the prominent, i.e. 7 th cervical vertebra)?

$5 \frac{1}{2}$. Height to knee (middle of patella)?

6. Height to perinaeum?

$6 \frac{1}{2}$. Pernaeum to most prominent part of pubes?

7. Breadth of neck?

$7 \frac{1}{2}$. Girth of neck?

8. Breadth of shoulders between acromion processes?

9. Breadth of pelvis between crests of ilia?

10. Circumference of chest across the nipples - a. full inspiration? b. after expiration?

$10 \frac{1}{2}$. Distance between nipples?

11. Circumference of waist above hips?

$11 \frac{1}{2}$. Circumference around hips on level with trochanters?

12.a. Length of arm - from tip of acromion to tip of middle finger?

b. Diatance from top of acromion to tip of middle finger?

c. Distance from tip of acromion to extremity of elbow?

13. Capacity of chest in cubic inches, (i.e. amount exhaled after full inhalation)?

14. Weight (lbs. and half lbs.) without coat, hat, arms, or acrcoutrements?

15. Dynamometer?

16. In the opinion of the Inspector, from appearance and statements of subject, is he of American stock of three or more generations? (In cases where this question cannot be answered with confidence, affirmatively or negatively, it will be best not to pursue the examination.)

17. If so, period of immigration of ancestry? (Detail of both sides desirable.)

18. Where born - country or state? county? parish or town?

19. If foreign born year of arrival in this country? Supposed about?

20. Country of birth - of father?

21. Enlisted - when? where? for what period?

22. Conjugal relation, (as single married or widower)?

23. Age (last birthday)?

24. Former occupation or occupations?

25. Hair - color? amount? texture? if bald at what age did baldness become distinct?

26. Eyes - color? distance between outer angles? distance between inner angles? prominent?

27. Complexion?

28. Pulse (regular) beats per minute?

29. Respiration (number of inspirations per minute, when quiet)?

30. Muscular development?

31. Is he in usual vigor? reduced by disease? wounds? recent exertion? hardship? poor fare?

32. Is he, when ordinarily well, a tougher and more vigorous man than before he entered the army?

33. Condition of teeth? number lost?

34. Head - a. circumference about frontal eminence and greatest projection of occiput?

b. distance between the condyloid processes of lower jaw over os frontis - longest measurement?

c. distance between condyloid processes over parietal bones?

d. distance between condyloid processes over occipital protuberance?

e. distance from frontal eminence to protuberance of occiput?

f. width between angles of jaw?

g. width between condyloid processes?

35. Facial angle?

51. Was he, before the war, given to athletic recreations, and if so, what kind?

55. Education. Limited common school? Good common school, High school, Collegiate, Professional?

Signature of Examiner

Place and date of examination 
Table 15: Comparison of White Soldiers in the Gould Sample with White Soldiers in the Union Army

\begin{tabular}{lrr}
\hline \hline & \multicolumn{1}{c}{$(1)$} & \multicolumn{1}{c}{$(2)$} \\
& Gould Sample & Union Army \\
\hline Percent of recruits born in New England & 11.5 & 13.8 \\
Percent of recruits born in Middle Atlantic & 37.3 & 24.7 \\
Percent of recruits born in North Central & 18.0 & 26.4 \\
Percent of recruits born in other U.S. states & 14.3 & 10.5 \\
Percent of recruits foreign-born & 19.9 & 24.6 \\
Percent of recruits farmers (age 18-34) & 44.4 & 53.4 \\
Mean height of recruits age 25-29 (cm) & 171.3 & 172.7 \\
Mean height of recruits age 30-34 (cm) & 171.3 & 172.8 \\
Mean height of recruits age 35 or over $(\mathrm{cm})$ & 171.0 & 172.6 \\
\hline \hline
\end{tabular}

Sources: Nativities in (1) are from Gould (1869: 256) and in (2) from Gould (1869: 104-105). Percent farmer in (1) is from the machine-readable Gould sample and in (2) from Fogel et al. (1990). Heights in (1) are from the machine-readable Gould sample and in (2) from Gould (1869: 27). The machine-readable Gould sample was restricted to white soldiers only (seamen were excluded).

- Height. In the Gould sample heights were measured with an andrometer.

- Weight. In the Gould sample weight was measured with platform scales graduated to quarters of a pound.

- Waist circumference. In the Gould sample waist circumference is measured as circumference of the waist above the hips and below the ribs. The midpoint is the natural waist circumference and this is what is measured in the 1950 and 1988 military surveys.

- Hip circumference. In the Gould sample circumference around the hips is measured on the level of the trochanters. This is generally, but not always, equivalent to measuring maximal buttock circumference. The 1950 and 1988 military samples use the latter measures.

- Chest circumference. Chest circumference was measured over the nipples and under clothing. For Form EE measurements, examiners were told to measure both while the lungs were fully inflated and after exhalation. No instructions were given for Form E. I used the mean value of circumference at maximal inspiration and circumference at full exhalation. The mean value calculated from Form EE was similar to that calculated from Form E. Restricting the sample to Form EE did not affect the mortality regressions. Both the 1950 and 1988 surveys measured chest circumference at the level of the nipples, but the 1950 instructions only specified that it be measured during natural breathing whereas the 1988 instructions specified that it be measured at the maximal point of quiet respiration. 
- Shoulder (biacromial) breadth. In Form E how breadth of shoulders was to be measured was unspecified but in Form EE it was measured as breadth of shoulders between the acromion processes. Means across the two forms, however, were similar. Both the 1950 and 1988 surveys measure biacromial diameter from acromion to acromion.

- Lifting Strength. Lifting strength was strength in pulling upward, as measured by a dynamometer. Because lifting strength depends upon how the dynamometer was constructed, measures in the Gould sample may not be comparable to recent measures.

- Vital Capacity. Vital capacity is measured by having the subject inspire maximally and then expire as rapidly and as completely as possible into a spirometer. Total lung capacity is reached at the point of maximal inspiration and residual volume is the amount of air left in the patient's lungs after maximal expiration. The difference between total lung capacity and residual volume is forced vital capacity, simply referred to as vital capacity in the paper. Measurements of vital capacity in the Gould sample understate true vital capacity and are not even comparable with measurements performed in the nineteenth century because of widespread differences in measurement by instrument (Hutchinson 1852). However, that vital capacity in the sample increases, as expected, with height and BMI, and decreases with age among men aged 25-49 provides evidence of its reliability within the Gould sample.

\section{References}

[1] Barker, D.J.P. 1992. Fetal and Infant Origins of Adult Disease. London: British Medical Journal Publishing Group.

[2] arker, D.J.P. 1994. Mothers, Babies, and Disease in Later Life. London: British Medical Journal Publishing Group.

[3] Blair D, Habicht JP, Sims EAH, et al. 1984. "Evidence for an increased risk of hypertension with centrally located body fat and the effect of race and sex on this risk." American Journal of Epidemiology. 119(4): 526-40.

[4] Clauser, Charles, Ilse Tebetts, Bruce Bradtmiller, John McConville, and Claire C. Gordon. 1988. Measurer's Handbook: U.S. Army Anthropometric Survey, 1987-1988. Technical Report Natick/TR-88/043.

[5] Costa, Dora L. Forthcoming. "Understanding Mid-Life and Older Age Mortality Declines: Evidence from Union Army Veterans." Journal of Econometrics.

[6] Costa, Dora L. 2002. "Changing Chronic Disease Rates and Long-term Declines in Functional Limitation Among Older Men.” Demography. 39(1): 119-138. 
[7] Costa, Dora L. 2000. "Understanding the Twentieth Century Decline in Chronic Conditions Among Older Men.” Demography. 37(1): 53-72.

[8] Costa, Dora L. 1996. "Health and Labor Force Participation of Older Men, 1900-1991." Journal of Economic History. 56(1): 62-89.

[9] Costa, Dora L. 1993. "Height, Weight, Wartime Stress, and Older Age Mortality: Evidence from the Union Army Records." Explorations in Economic History. 30: 424-449.

[10] Costa, Dora L. and Richard H. Steckel. 1997. "Long-Term trends in Health, Welfare, and Economics Growth in the United States." In R. Floud and R.H. Steckel (Eds), Health and Welfare During Industrialization. Chicago: University of Chicago Press for NBER,

[11] Eisen, E.A., D.W. Dockery, F.E. Speizer, M.E. Fay, and B.G. Ferris, Jr. 1987. "The Association Between Health Status and the Performance of Excessively Variable Spirometry Tests in a Population-based Study in Six U.S. Cities." American Review of Respiratory Disease. 136: 1371-6.

[12] Floud, Roderick, Kenneth W. Wachter, and Anabel S. Gregory. 1990. Height, Health, and History: Nutritional Status in the United Kingdom, 1750-1980. Cambridge: Cambridge University Press.

[13] Fogel, Robert W. 1992. "The Body Mass Index of Adult Male Slaves in the U.S. c. 1863 and Its Bearing on Mortality Rates." In Robert W. Fogel, Ralph A. Galantine, and Richard L. Manning, Eds, Without Consent or Contract: Evidence and Methods. New York: W.W. Norton and Company.

[14] Fogel, Robert W. 1993. "New Sources and New Techniques for the Study of Secular Trends in Nutritional Status, Health, Mortality, and the Process of Aging." Historical Methods. 28(1): 5-44.

[15] Fogel, Robert W. and Dora L. Costa. 1997. "A Theory of Technophysio Evolution, With Some Implications for Forecasting Population, Health Care Costs, and Pension Costs." Demography. 34(1): 49-66.

[16] Fogel, Robert W., Stanley E. Engerman, Clayne Pope, and Larry Wimmer. 1990. Union Army Recruits in White Regiments in the United States, 1861-1865. [Computer file]. Ann Arbor, MI: Inter-university Consortium for Political and Social Research [distributor]. .

[17] Folsom AR, Prineas RJ, Kaye SA, et al. 1989. "Body fat distribution and self-reported prevalence of hypertension, heart attack, and heart disease in older women." International Journal of Epidemiology. 18(2): 361-7.

[18] Folsom AR, Kaye SA, Sellers TA, Hong CP, Cerhan JR, Potter JD, Prineas RJ. 1993. "Body Fat Distribution and 5-Year Risk of Death in Older Women." Journal of the American Medical Association. 269(4): 483-87. 
[19] Freedman, D.S., D.F. Williamson. J.B. Croft, C. Ballew, and T. Byers. 1995. "Relation of Body Fat Distribution to Ischemic Heart Disease. The National Health and Nutrition Examination Survey I (NHANES I) Epidemiologic Follow-up Study. American Journal of Epidemiology. 142(1): 53-63.

[20] Goldin, Claudia and Robert A. Margo. 1989. "The Poor at Birth: Birth Weights and Infant Mortality at Philadelphia's Almshouse Hospital, 1848-1873." Explorations in Economic History. 26: 360-379.

[21] Gould, Benjamin Apthorp. 1869. Investigations in the Military and Anthropological Statistics of American Soldiers. New York: Published for the United States Sanitary Commission, by Hurd and Houghton. Cambridge: Riverside Press.

[22] Haines, Michael R., Lee A. Craig, and Thomas Weiss. 2000. "Development, Health, Nutrition, and Mortality: The Case of the "Antebellum Puzzle" in the United States." National Bureau of Economic Research Historical Paper 130.

[23] Hertzberg, H.T.E., G.S. Daniels, and E. Churchill. 1954. WADC (Wright Air Development Center) Technical Report 52-321.

[24] Hutchinson, J. 1852. The Spirometer, the Stethoscope, and Scale-balance; their use in discriminating diseases of the chest, and their value in life offices; with remarks on the selection of lives for life assurance companies. London: John Churchill, Prince Street, Soho.

[25] Lagerström, M, K. Bremme, P. Eneroth, and C-G Janson. 1994. "Long-term Development for Boys and Girls at Age 16-18 as Related to Birth Weight and Gestational Age. International Journal of Psychophysiology. 17(2):175-80.

[26] Loomis, D.P., G.W. Collman, W.J. Rogan. 1989. "Relationship of Mortality, Occupation, and Pulmonary Diffusing Capacity to Pleural Thickening in the First National Health and Nutrition Examination Survey.” American Journal of Industrial Medicine. 16: 477-84.

[27] Loos, R.J., G. Beunen., R. Fagard, C. Derom, and R. Vlietinck. 2001. International Journal of Obesity. 25(10): 1537-45.

[28] Martinez, F.D., L.M. Taussig, and W.J. Morgan. 1990. "Infants with Upper Respiratory Tract Illnesses Have Significant Reductions in Maximal Respiratory Flow." Pediatric Pulmonology. 9: 91-5.

[29] Martorell, R., U. Ramakrishnan, D.G. Schroeder, P. Melgar, and L. Neufeld. "Intrauterine Growth Retardation, Body Size, Body Composition, and Physical Performance in Adolescence.” 1996. In Nevin S. Scrimshaw and Beat Schürch, Eds. Causes and Consequences of Intrauterine Growth Retardation. Proceedings of an I/D/E/C/G/ Workship held in Baton Rouge, USA, November 11-15, 1996. http://www.unu.edu/unupress/food2/UIDO3E//uid03e00.htm 
[30] Ohlson LO, Larsson B, Svardsudd K, et al. 1985. "The influence of body fat distribution on the incidence of diabetes mellitus. 13.5 years of follow-up of the participants in the study of men born in 1913." Diabetes. 34(10): 1055-8.

[31] Okosun, I.S., S.H. Tedders, S. Choi, and G.E. Dever. 2000. "Abdominal Adiposity Values Associated with Established Body Mass Indexes in White, Black, and Hispanic Americans. A Study from the Third National Health and Nutrition Examination Survey. International Journal of Obesity and Related Metabolic Disorders. 24(10): 1279-85.

[32] Paz, I, D.S. Seidman, Y.L. Dnon, A. Laor, D.K. Stevenson, and R. Gale. 1993. American Journal of Diseases of Children. 147(3): 337-9.

[33] Prince, Joseph M. and Richard H. Steckel. 2001. "Tallest in the World: Native Americans of the Great Plains in the Nineteenth Century." American Economic Review. DATE?

[34] Schreiner, P.J., J.G. Terry, G.W. Evans, W.H. Hinson, Crouse Jr 3rd, G. Heiss. 1996. American Journal of Epidemiology. 144(4): 335-45.

[35] Steckel, Richard H. 1986. "A Peculiar Population: The Nutrition, Health, and Mortality of American Slaves from Childhood to Maturity." Journal of Economic History 46: 721-41.

[36] Strachan, D.P. 1991. "Ventilatory Function as a Predictor of Fatal Stroke." British Medical Journal. 302: 84-7.

[37] Terry Richard B., William F. Page, and William L. Haskell. 1992. "Waist/hip ratio, body mass index and premature cardiovascular disease mortality in US Army veterans during a twenty-three year follow-up study." International Journal of Obesity. 16(6): 417-23.

[38] Ward, Peter W. 1993. Birth Weight and Economic Growth: Women's Living Standards in the Industrializing West. Chicago: University of Chicago Press.

[39] Yao, Chong-Hua, Martha L. Slattery, David R. Jacobs, Jr, Aaron R. Folsom, and Eileen T. Nelson. 1991. American Journal of Epidemiology. 134(11): 1278-1289. 